\title{
Biology and population features of a rare species of Pseudopimelodidae from the Upper Paraná River Basin
}

\author{
André Luiz, Henríques Esguícero ${ }^{1,2}$ \& Marlene Sofia Arcifa ${ }^{1}$ \\ ${ }^{1}$ Programa de Pós-graduação em Biologia Comparada, Laboratório de Limnologia, \\ Departamento de Biologia, Universidade de São Paulo - USP, \\ Av. Bandeirantes, 3900, CEP 14040-901, Ribeirão Preto, SP, Brasil \\ ${ }^{2}$ Corresponding author: André Luiz. Henríques Esguícero, e-mail: andre.esguicero@gmail.com
}

ESGUÍCERO, A.L.H. \& ARCIFA, M.S. Biology and population features of a rare species of Pseudopimelodidae from the Upper Paraná River Basin. Biota Neotrop. 10(3): http://www.biotaneotropica.org.br/v10n3/en/ abstract?article+bn03010032010.

\begin{abstract}
Streams contain an expressive fraction of the South American fish diversity, mostly composed of smallsized, endemic, and rare species. Populational, reproductive, and diet aspects of Microglanis garavelloi were studied, aiming to make a wide characterization of this species of bumblebee catfish. This is an endemic species of the Upper Paraná River Basin, and the only representative of the genus in the watershed. It is a littoral-dweller of small rivers, with asymptotic length of $34.1 \mathrm{~mm}$ and a population mostly composed of individuals with $20-30 \mathrm{~mm}$ of standard length. This species presents high fecundity and mortality rate, and low longevity and growth rate. It is a total spawner, October to February being the spawning period, and probably has brood care behavior, as has been already observed for some Heptapteridae species. The species can be considered an active predator, probably presenting benthic life like most siluriforms, having a diet uniquely composed of aquatic insect larvae. This species occurs as small populations patchily distributed in the Upper Paraná River Basin. This population characteristic, combined with the progressive environmental degradation of its habitats, points to a situation of constant threat that could lead to an irreversible extinction process.
\end{abstract}

Keywords: siluriformes, conservation, population structure, reproductive dynamics, diet.

ESGUÍCERO, A.L.H. \& ARCIFA, M.S. Biologia e características populacionais de uma espécie rara de Pseudopimelodidae da Bacia do Alto Rio Paraná. Biota Neotrop. 10(3): http://www.biotaneotropica.org.br/ v10n3/pt/abstract?article+bn03010032010.

Resumo: Rios de pequeno porte abrigam uma importante fração da diversidade ictiofaunística sul-americana, caracterizada principalmente por espécies endêmicas, raras e de pequeno porte. Com o objetivo de realizar uma ampla caracterização da espécie Microglanis garavelloi, encontrada em pequenos corpos d'água da Bacia do Alto Rio Paraná, foram estudados alguns de seus aspectos populacionais, reprodutivos e alimentares. Essa espécie é endêmica do Alto Rio Paraná, sendo a única representante do gênero nessa bacia. Ela ocupa principalmente a região litorânea de pequenos rios, apresenta comprimento assintótico de $34,1 \mathrm{~mm}$, e população composta principalmente por indivíduos com comprimento padrão entre 20 e $30 \mathrm{~mm}$. Esta espécie apresenta alta fecundidade, alta taxa de mortalidade, baixa longevidade e baixa taxa de crescimento. Além disso, apresenta desova total, que ocorre de outubro a fevereiro e, provavelmente, apresenta comportamento de cuidado com a prole, como já observado em algumas espécies de Heptapteridae. Sua dieta é baseada unicamente em larvas de insetos aquáticos, podendo ser considerada uma predadora com comportamento alimentar ativo e, provavelmente, apresenta vida bentônica, como a maioria dos Siluriformes. Esta espécie ocorre como populações pequenas com distribuição fragmentada na bacia do Alto Rio Paraná. Esta característica populacional, acrescida da constante degradação ambiental em seus hábitats, indica uma situação de constante ameaça que pode levar a um irreversível processo de extinção. Palavras-chave: siluriformes, conservação, estrutura populacional, dinâmica reprodutiva, dieta. 


\section{Introduction}

The Upper Paraná River Basin includes the watershed located upstream the extinct Sete Quedas Falls, a natural barrier that was covered by the Itaipu Reservoir in 1982. The known fish fauna is composed of 310 species, most of them belonging to the orders Characiformes and Siluriformes. Most of the fish fauna (ca. 65\%) is composed of small-sized species, i.e, smaller than $20.8 \mathrm{~cm}$ standard length (Langeani et al. 2007). These small-sized fishes are the main component of the fish fauna of small water bodies which, although harboring most of the fish diversity of South American intracontinental waters, are relatively little studied (Castro et al. 1999).

The small- and medium-sized natural running waters are generally ecosystems of high endemism for fishes (Castro et al. 1999), as well as habitats of rare species. The Upper Paraná River Basin is a region of high endemism (Vari 1992), and because of its location in Southern Brazil, the most economically developed region in the country, it is subjected to an intense anthropic degradation process. Pollution, eutrophication, silting, and river damming are the main causes of biodiversity losses in these aquatic ecosystems (Agostinho et al. 2005). Degradation of streams and creeks is potentially more deleterious since those habitats are prone to a high endemism (Castro et al. 1999), leading to a rapid and irreversible loss of an important fraction of the Brazilian fish fauna diversity. In view of this scenario, the knowledge on the biology and population dynamics of fishes in those unique environments are extremely important for management and conservation policies concerning the fish fauna diversity in Brazilian continental water bodies.

The family Pimelodidae has been recently split into three monophyletic groups (Lundberg et al. 1991, De Pinna 1998): Pseudopimelodidae, Pimelodidae and Heptapteridae. Differing from the other two groups, the family Pimelodidae is represented by a high number of large-sized species, generalist carnivores or omnivores that present sedentary and migratory behavior, and apparently do not have parental care (reviewed by Lundberg \& Littmann 2003). The family Heptapteridae is represented by a high number of small-sized species (Bockmann \& Guazzelli 2003), mostly carnivorous or omnivorous that present sedentary behavior and no parental care. In general, they have long reproductive periods along the year (reviewed by Bockmann \& Guazzelli 2003), characteristic of species of water bodies with highly variable physical and chemical factors (Garutti 1989, Vazzoler 1996); however, there are exceptions, like Pimelodella pappenheimi Ahl, 1925, that reproduces seasonally (Amaral et al. 1998).

Pseudopimelodidae is a family of siluriforms recently described and is composed of six genera (Shibatta 2003, Ferraris 2007) and a high number of small-sized species (Ferraris 2007). The biology of the species of Pseudopimelodidae is poorly known (Shibatta 2003), except for the threatened species Lophiosilurus alexandri Steindachner, 1877 (Rosa \& Menezes 1996). Some aspects known for other species are the reproductive patterns of Microglanis iheringi Gomes, 1946 that shows parental care (Winemiller 1989) and, like L. alexandri, has eggs with large diameter $(1.1 \mathrm{~mm})$. Microglanis carlae Alcaraz et al. (2008) feed on algae and insect larvae, and Microglanis pataxo Sarmento-Soares et al. (2006) consumes larvae and pupae of aquatic insects (Sarmento-Soares et al. 2006, Alcaraz et al. 2008).

The genus Microglanis Eigenmann (1912), currently composed of 17 species (Alcaraz et al. 2008), is represented only by Microglanis garavelloi Shibatta \& Benine, (2005) in the Upper Paraná River basin. This species has been previously recorded in a few streams and rivers of the Paranapanema River Basin (Taquari and Pau D'Alho streams) and of Tietê River Basin (Pirapitingui and Barreiro Rivers), and is reported as a rare species. This species of Pseudopimelodidae differs from congeneric species mainly by morphometric characters and color pattern, as described in detail by Shibatta \& Benine (2005).
This study aimed to add information on the endemic and rare M. garavelloi, a bumblebee catfish. We present information on its populational (growth, mortality and longevity), reproductive (average length at first gonadal maturation, sex ratio, reproductive period, relative fecundity and spawning type) aspects and diet in a small river of the Tietê River, in the Upper Paraná River Basin.

\section{Materials and Methods}

\section{Study area}

Boa Esperança is a third-order river which runs for $40 \mathrm{~km}$ before flowing into the left margin of the Jacaré-Guaçu River, a tributary of the right margin of the Tietê River, one of the main tributaries of the left margin of the Upper Paraná River (Figure 1). The Boa Esperança basin area covers approximately 140.000 ha, located in the towns of Dourado and Ribeirão Bonito (headwaters), Trabiju, and Boa Esperança do Sul (maincourses). Intensive agriculture and cattle raising activities are developed in the region, such as sugar cane plantation (which covers $40 \%$ of the area), pastures $(17 \%$ ), and orange culture (13\%) (CATI/LUPA 2008). Fragments of natural vegetation contribute $17 \%$, and are composed mostly of seasonal semi-decidual and riparian forests and cerrado fields (savannas) (Hueck \& Seibert 1981).

The natural vegetation of the study area is impacted by anthropic action, the river banks presenting eroded areas, owing to the suppression of the riparian vegetation by agricultural and cattle raising activities and the construction of fishermen huts. A significant part of the original vegetation has been replaced by the exotic grass Brachiaria spp. and bushes. The river banks are not inclined and expand into a floodplain during the wet season. The study area (Figure 2), located near the confluence of the Boa Esperança River and the Jacaré-Guaçu River ( $21^{\circ} 52^{\prime} 16^{\prime \prime} \mathrm{S}$ and $48^{\circ} 31^{\prime} 02^{\prime \prime} \mathrm{W}$ ), is $8 \mathrm{~m}$ wide $(\mathrm{SD} \pm 0.6 \mathrm{~m}$ ) and the sediment is mostly composed of sand.

\section{Environmental characterization}

During the sampling period, a field observational characterization of the river banks and their vegetation and the substrate type of the river bed was carried out. The width of the river was measured with a metric tape, and the current velocity by the method of a floating object (Bower \& Zar 1984). Abiotic factors also evaluated were the Secchi disk transparency with a $30 \mathrm{~cm}$-white disk, temperature, dissolved oxygen, electrical conductivity, and $\mathrm{pH}$ with Yellow Springs Inc. equipment. The river flow in each month was estimated using data on monthly variation of the depth, measured at a fixed point, the average width of the stretch and the monthly variation of the current velocity.

\section{Sampling}

Sampling was carried out monthly from November 2007 to October 2008. Due to the small size of the adults, the sampling gear used for catching specimens of Microglanis garavelloi were a rectangular sieve $(100 \times 70 \mathrm{~cm}$ and $5 \mathrm{~mm}$ mesh size $)$, used in the banks, and a seine net ( $10 \mathrm{~m}$ long $\times 2 \mathrm{~m}$ high and $5 \mathrm{~mm}$ mesh size), dragged from the river channel towards an open clean margin. The sampling was performed at sunset and the effort was standardized. The seine net was passed twice and the rectangular sieve 20 times.

The specimens captured were immediately fixed with $10 \%$ formalin and then transferred to $70 \%$ ethanol. In the laboratory, the specimens were weighed using a digital scale and measured (standard length - SL) with a caliper rule. Voucher specimens (LIRP 7539) are available in the Fish Collection of the Laboratory of Ichthyology of Ribeirão Preto (LIRP). 

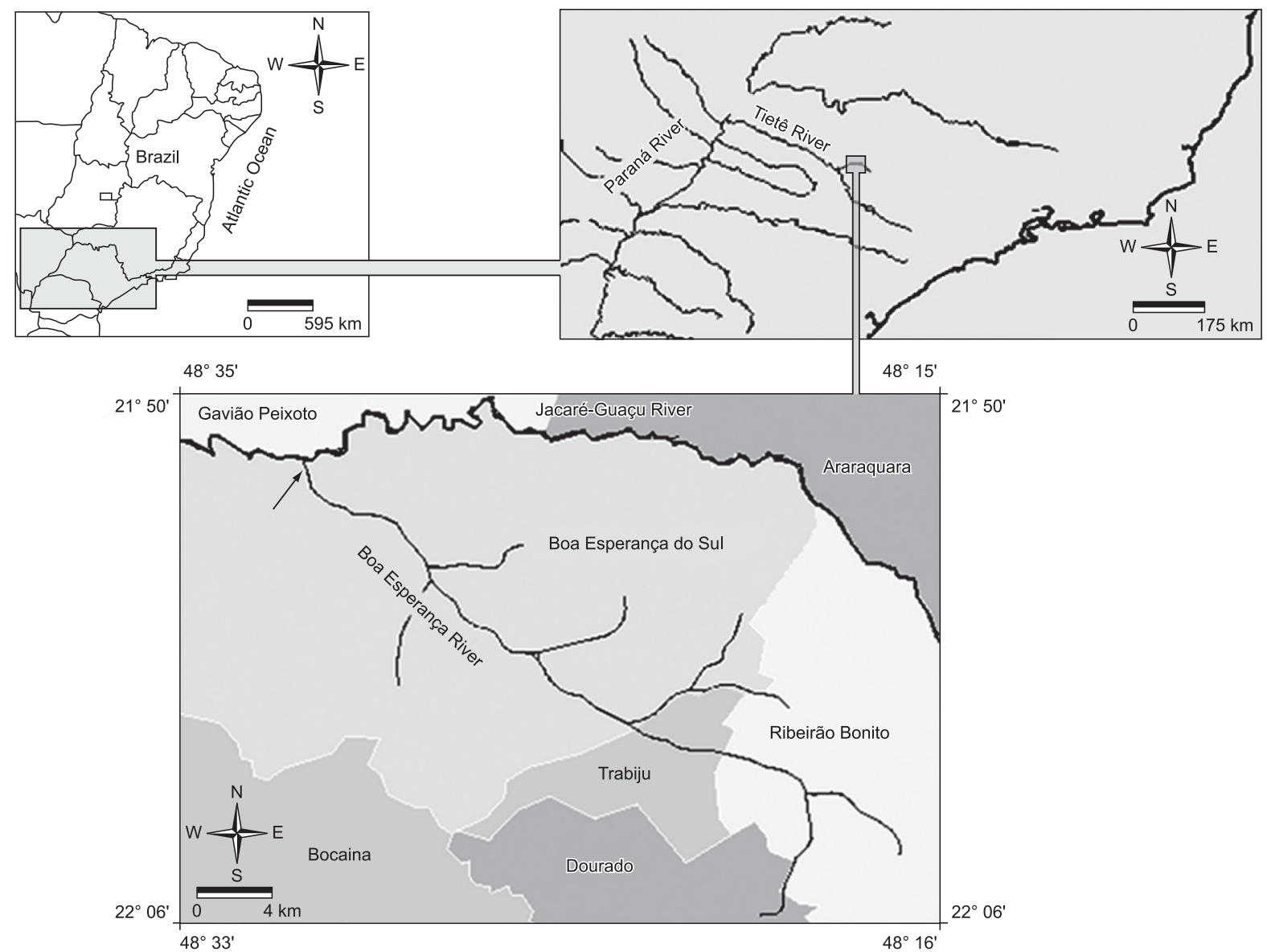

Figure 1. Location of the Boa Esperança River basin in the Upper Paraná River basin, Southern Brazil. The black arrow indicates the study area.
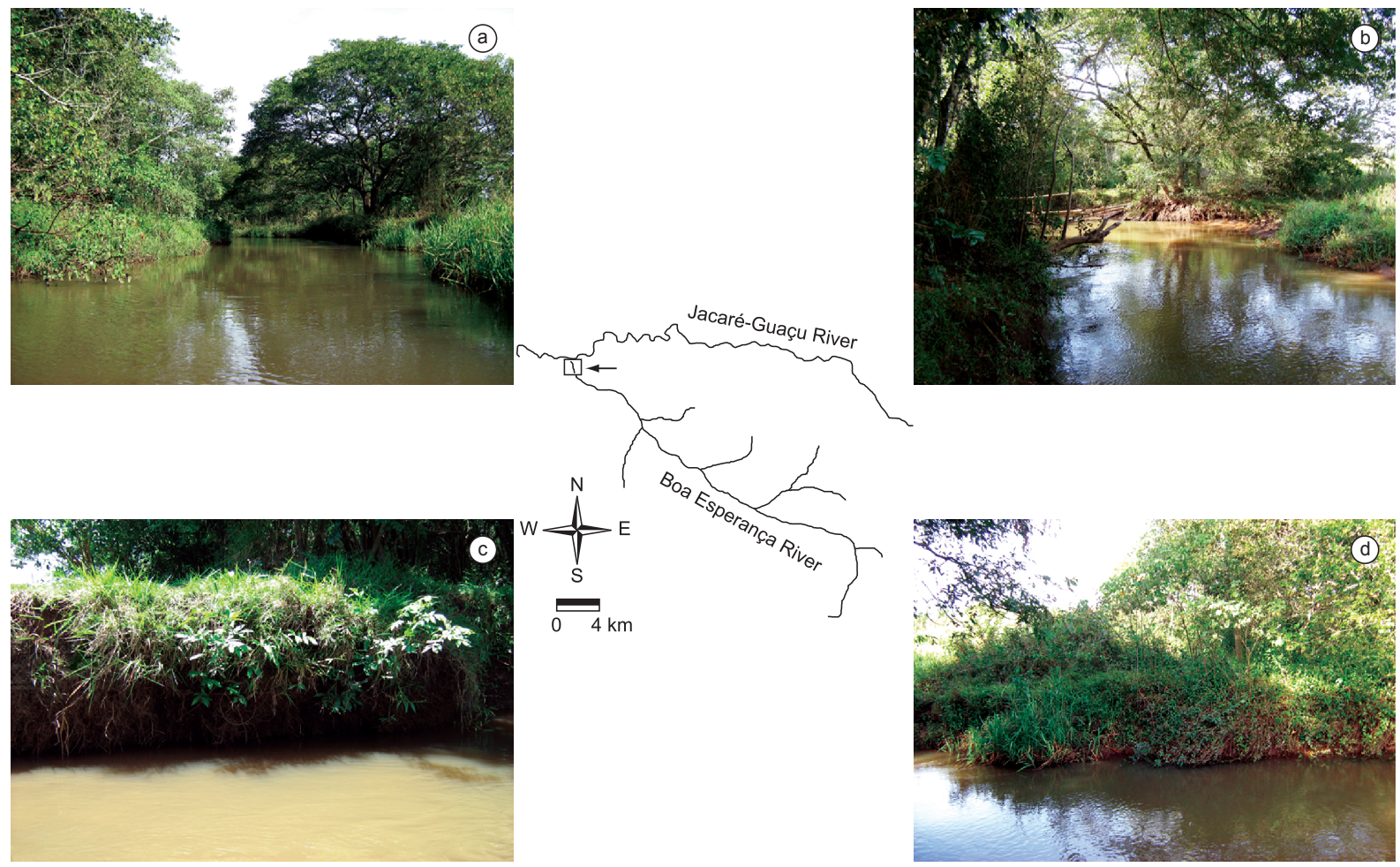

Figure 2. Location of the study area in the Boa Esperança River basin (black arrow). a) upstream view of the study area; b) downstream view of the study area; c) left margin; d) right margin. 


\section{Populational aspects}

As the number of captures of this rare species was very low, only an estimative of parameters like growth and mortality was made, using the FISAT II software (Gayanilo et al. 2005). More details on the methods can be found in Castro et al. (2002), Gomiero et al. (2007) and Carmassi et al. (2008). Only natural mortality (Pauly 1980) was considered because the species is not commercially exploited and fishing was not considered as an additional mortality rate. Longevity, defined as the time to reach $95 \%$ of the asymptotic length, was estimated according to the formula proposed by Taylor (1958): $\mathrm{t}_{\max }=\mathrm{t}_{0}+2.996 / \mathrm{k}$, where $\mathrm{k}$ is the growth coefficient, $\mathrm{t}_{0}$ is the theoretical age of fish at zero length.

\section{Reproductive aspects}

Four gonadal developmental stages were determined for the specimens caught, according to Vazzoler (1996): resting, maturing, mature, and spawned. Based on these data the average length at first maturation $\left(L_{50}\right)$, when $50 \%$ of the population is composed of adults, and the length when $100 \%$ of the individuals are adults $\left(L_{100}\right)$, was estimated following the methodology proposed by Vazzoler (1996). Size classes of $2.5 \mathrm{~mm}$ were established for the whole catch. The sex ratio for the whole sample was calculated and the chi-square test was applied, at 5\% significance level, for verifying differences among the ratios.

Because it is a rare species, with a small number of catches per sampling (Shibatta \& Benine 2005), an indicative of the reproductive period was determined through the analysis of the females' monthly distribution of gonadal developmental stages, average gonad-somatic ratio (RGS), and averages of $\Delta \mathrm{K}$ (difference between the total condition factor $(\mathrm{K})$ and the somatic condition factor $\left.\left(\mathrm{K}^{\prime}\right)\right)$. The RGS, which expresses the gonadal percentage of the total weight, is an efficient indicator of the ovary functional stage (reviewed by Vazzoler 1996). The RGS was obtained by the equation: $\mathrm{W}_{\mathrm{g}} / \mathrm{W}_{\mathrm{t}} \times 100$, where $\mathrm{W}_{\mathrm{t}}=$ total weight and $\mathrm{W}_{\mathrm{g}}$ = gonadal weight.

The $\Delta \mathrm{K}$ represents the portion of energy reserves transferred to the gonads, being a good indicator of the reproductive period (reviewed by Vazzoler 1996). The following equations were used: $\mathrm{K}=\mathrm{W}_{\mathrm{t}} / \mathrm{SL}^{\mathrm{b}}$, where $\mathrm{SL}=$ standard length and $\mathrm{b}=$ angular coefficient of the regression between $\mathrm{W}_{\mathrm{t}} \sim \mathrm{SL}$; and $\mathrm{K}^{\prime}=\mathrm{W}_{\mathrm{c}} / \mathrm{SL}^{\mathrm{b}}$, where $\mathrm{W}_{\mathrm{c}}=\mathrm{W}_{\mathrm{t}}-\mathrm{W}_{\mathrm{g}}$ and $\mathrm{b}=$ angular coefficient of the regression between $\mathrm{W}_{\mathrm{c}} \sim \mathrm{SL}$.

The relative fecundity, measured as the number of oocytes by SL unit (mm) (Vazzoler 1996), was evaluated using mature females. The spawning type, defined as the way females release the mature oocytes within a reproductive period (reviewed by Vazzoler 1996), was determined by the relative frequency of diameter classes $(0.07 \mathrm{~mm})$ of oocytes.

\section{Diet}

The diet of the species was evaluated by the stomach content analysis for each specimen under a stereomicroscope. The stomach content was placed on a square grid counting chamber, the total area occupied by all items being considered as the total volume, where each item represents a fraction of the whole volume. The method followed was the "Subjective Method" for stomach content analyses, one of several methods presented by Hyslop (1980).

The dietary items were identified to order or family, with the aid of specific literature. The percentage of occurrence was the number of specimens containing the item $I$ relative to the total number of individuals analyzed. To evaluate the degree of stomach repletion, we adopted the classification, based on food volume (Hahn et al. $1997)$ : empty, partially empty ( $\leq 25 \%)$, partially full $(25-75 \%)$ and full $(>75 \%)$.

\section{Results}

\section{Environmental characterization}

Dissolved Oxygen (DO) concentrations and $\mathrm{pH}$ showed a small temporal variation (Figure 3) with average values of $6.2 \mathrm{mg} . \mathrm{L}^{-1}$ $(\mathrm{SD} \pm 0.3)$ and $6.7(\mathrm{SD} \pm 0.1)$, respectively. From October to March, it was observed the higher average values of water temperature, flow, rainfall, conductivity, and DO, and the lower average values of transparency and $\mathrm{pH}$. From April to September, lower average values of water temperature, flow, rainfall, conductivity, and DO, and higher average values of transparency and $\mathrm{pH}$ were recorded.

\section{Population aspects}

Despite a high effort spent on seining, only the rectangular sieve resulted in catching specimens of Microglanis garavelloi. Specimens were littoral-dwellers, rarely moving into the river channel. On average, 2.8 individuals per monthly sampling were captured, totalizing 34 specimens, which were caught in marginal areas (Figure 2), containing a mixture of submerged tree branches and roots.

The asymptotic length was $34.1 \mathrm{~mm} \mathrm{SL}$, the estimated growth rate $9.7 \mathrm{~mm} /$ year, and the natural mortality rate 1.5 . The estimated longevity indicates that the species might reach 37 months.

\section{Reproductive aspects}

Twenty three out of the 34 specimens caught were adults. The average length at first maturation $\left(\mathrm{L}_{50}\right)$ and the average length $\left(\mathrm{L}_{100}\right)$ were, respectively, 22.7 and $30.1 \mathrm{~mm}$ SL. The sex ratio female:male was 17:6, differing statistically from $1: 1\left(x^{2}=21.66\right.$, $\mathrm{df}=1$, $\mathrm{p}<0.05)$.

The highest average values of the gonad-somatic ratio were recorded from October to February, a peak occurring in December (Figure 4). The highest $\Delta \mathrm{K}$ values were found in the same period, with a peak in February. These data and the presence of mature individuals only from December to February (Figure 4) indicate that the reproductive period is from October to February.

The relative fecundity was 13.9 oocytes per $\mathrm{mm}$ SL. The frequency distribution of the diameter of oocytes (Figure 5) indicates that all the oocyte cells present a concomitant maturation, being released at once during the reproductive period.

\section{Diet}

Of the 34 stomachs analyzed, full stomachs were not observed, and the majority was empty $(47 \%)$ or partially empty $(41 \%)$, the remaining (12\%) being partially full. Accordingly, the content of 18 stomachs was analyzed, and only one type of dietary item was found in each. The diet of juveniles and adults of $M$. garavello $i$ was entirely composed of autochthonous items, mostly aquatic insects, belonging to Chironomidae (Diptera) (55.6\% of the stomachs analyzed), Ephemeroptera (33.3\%), Lepidoptera (5.6\%) and other Diptera (5.6\%). Chironomid larvae were the most frequent item, which together with Ephemeroptera nymphs amounted to $88.9 \%$ of the stomachs whose content was analyzed. Apparently, the specimens less than $22.9 \mathrm{~mm}$ SL $(n=6)$ feed only on chironomids and larger specimens $(n=12)$ on chironomids, mayflies, other dipterans, and lepidopterans.

\section{Discussion}

M. garavelloi is an insectivorous species, and has been found so far in small lotic environments (Shibatta \& Benine 2005), such as the Boa Esperança River, where it is a littoral-dweller, in areas with submerged branches and roots. The population analyzed in this study is mostly composed of individuals with $20-30 \mathrm{~mm} \mathrm{SL}$, the asymptotic 

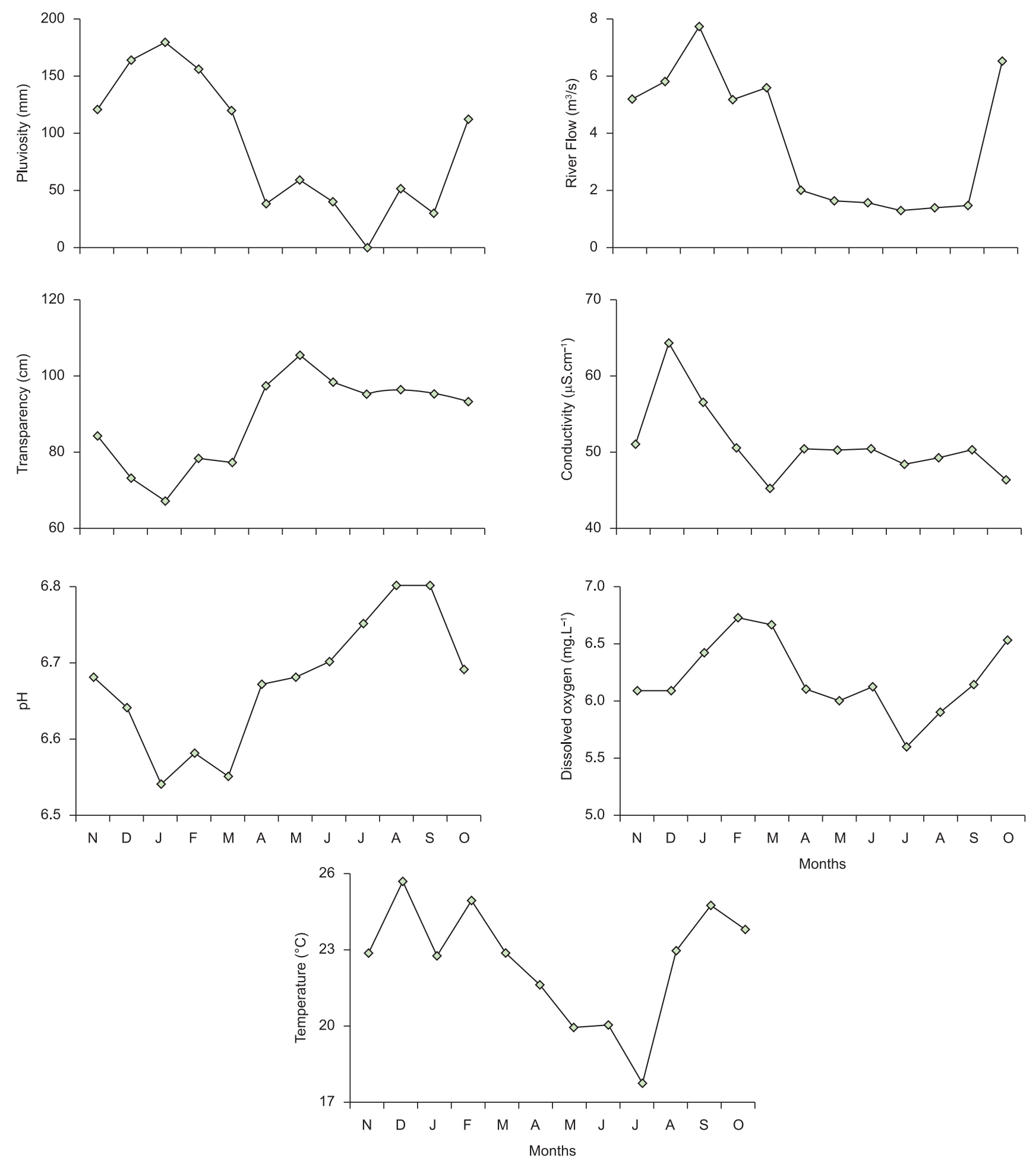

Figure 3. Monthly variation, from November 2007 to October 2008, of physical and chemical factors in the study area.

length $(31.4 \mathrm{~mm})$ being smaller than the maximum size $(41.8 \mathrm{~mm}$ SL) reported by Shibatta \& Benine (2005). Based on the growth rate, the species reach its asymptotic length in approximately three years and the average length at first gonadal maturation in approximately two years. Taking into account the low longevity of this population, the growth rate can be considered slow. It presents high mortality and fecundity rates, and all the oocyte cells mature at the same time, being released at once during the spawning period, which occurs from October to February. A high predation rate could be an explanation for the high natural mortality rate of this species. High natural mortality rates are common among Brazilian fishes (Lizama \& Ambrósio 2003, Gomiero et al. 2007, Carmassi et al. 2008), as well as among tropical fishes in general (Pauly 1998), and can be compensated by high fecundity as shown by $M$. garavelloi. 

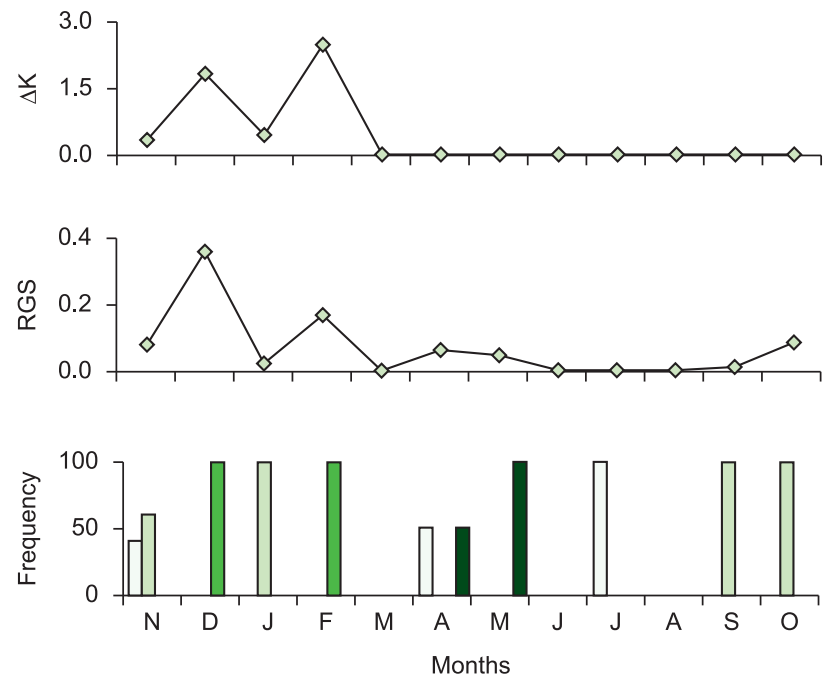

$\square$ Resting $\square$ Maturing $\square$ Mature $\square$ Spawned

Figure 4. Monthly variation of the gonad-somatic index (RGS), $\Delta \mathrm{K}$ values, and the frequency of the gonadal stages of Microglanis garavelloi.

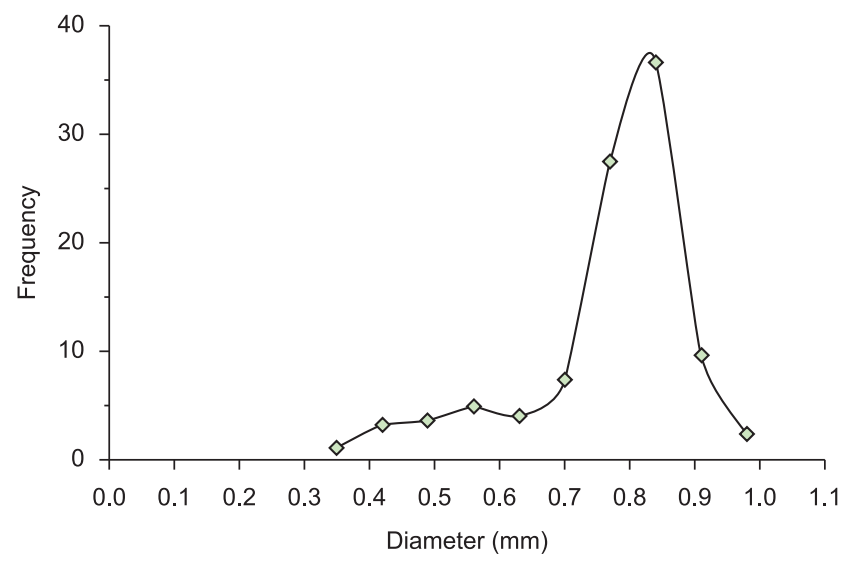

Figure 5. Pattern of the frequency distribution of oocyte diameter in Microglanis garavelloi.

As reviewed by Vazzoler (1996), individuals that reach the size/ age at first maturation, $22.7 \mathrm{~mm} \mathrm{SL}$ in the case of M. garavelloi, are influenced by a set of environmental variables, and the reproductive period, from October to February for this species, will occur during the most favorable environmental conditions to the offspring growth and survival. In this particular period, higher concentrations of dissolved oxygen and lower transparencies can, respectively, provide a better aeration for eggs and larvae and lower predation risk, vital factors for the survival of the early life stages of fishes (Vazzoler 1996).

In general, fish species of small water bodies present multiple spawning as an adaptation to increase survival chances (Garutti 1989, Vazzoler 1996). These environments are mainly characterized by ephemeral floods, which strongly disturb the habitat and could lead to a higher loss of eggs, or early life stages, mainly due to the sudden rising flow, which consequently increases the drift (Amaral et al. 1998). According to Machado-Allison (1990) and Amaral et al. (1998), some Heptapteridae try to avoid such problems by placing the eggs or hiding themselves under leaves, tree branches, and submerged roots or by burrowing into the sediment. Such kind of brood care behavior could minimize offspring losses of $M$. garavelloi during floods, since it seems to present total spawning and seasonal reproduction, as Pimelodella pappenheimi (Amaral et al. 1998), synchronized with flood periods. Parental care behavior could not be confirmed in this study, but was reported for $M$. iheringi (Winemiller 1989).

According to Nikolsky (1963), the sex ratio in fish populations can vary annually, by metabolic changes under the influence of hormones, leading to unbalanced ratios. Besides, different mortality, growth, spatial segregation, and/or behavior for males and females during the life cycle could determine a change in the sex ratio and the predominance of one sex (reviewed by Vazzoler 1996). Therefore, the higher proportion of females in the population of $M$. garavelloi could be the result of different factors.

Microglanis garavelloi is an insectivorous species. Aquatic insects are also dietary items of M. pataxo and M. carlae (SarmentoSoares et al. 2006, Alcaraz et al. 2008). Probably, M. garavelloi has benthic behavior, not differing from other siluriforms (Bockmann \& Guazzelli 2003) that feed on the river substrate. The absence of other items in the stomachs, such as detritus and sediments, indicates a selective behavior of picking up items on the substrate, as observed in the small-sized catfish $P$. pappenheimi (Aranha et al. 1998). M. garavelloi has a large head, a terminal mouth with an ample gape, a large caudal fin, and the transversal section of the caudal peduncle relatively large (Shibatta \& Benine 2005). All these characteristics are associated to carnivorous species and active hunters with high swimming power (Teixeira \& Bennemann 2007). The active hunter behavior was observed in various small-sized species of Heptapteridae, which dig the substrate in search of preys (reviewed by Bockmann \& Guazzelli 2003). Ontogenetic variation of the fish diet is commonly found, which could be a consequence of distinct energetic requirements of the developmental stages and/or of morphological limitations (Abelha et al. 2008). Despite the small number of specimens analyzed, it seems that chironomids are the main dietary item of small individuals $(<22.9 \mathrm{~mm})$ of M. garavelloi. This result could be related to a limited predation owing to a smaller mouth gape and a lower motion power. These features must be enhanced during the life cycle, leading to a larger food size spectrum and a greater foraging capacity.

As recorded by Shibatta \& Benine (2005), the number of individuals of $M$. garavelloi captured per collection event was very low (mean $=2.8$ ), indicating the possible existence of small populations. According to these authors, the distribution of this species in the Upper Paraná River Basin indicates the existence of discrete populations distributed in patches in small rivers of the basin. This population characteristic, combined with the progressive environmental degradation of its habitats, point to a situation of constant threat that could lead to an irreversible extinction process.

\section{Acknowledgements}

We thank RMC Castro and the Laboratório de Ictiologia de Ribeirão Preto, Universidade de São Paulo, Ribeirão Preto, specially FCP D'Agosta and TNA Pereira who helped in the field work, and CAPES (Coordenação de Aperfeiçoamento de Pessoal de Nível Superior) for a grant to ALHE. We also thank the Programa de Pós-Graduação em Biologia Comparada da Universidade de São Paulo for financial support and two anonymous referees for valuable suggestions on the manuscript. 


\section{References}

ABELHA, M.C.F., AGOSTINHO, A.A. \& GOULART, E. 2008. Plasticidade trófica em peixes de água doce. Acta Sci. Biol. Sci. 23(1):425-434.

AGOSTINHO, A.A., THOMAZ, S.M. \& GOMES, L.C. 2005. Conservação da biodiversidade em águas continentais do Brasil. Megadiversidade 1(1):70-78

ALCARAZ, H.S.V., GRAÇA, W.J. \& SHIBATTA, O.A. 2008. Microglanis carlae, a new species of bumblebee catfish (Siluriformes: Pseudopimelodidae) from the rio Paraguay basin in Paraguay. Neotrop. Ichthyol. 6(3):425-432.

AMARAL, M.F., ARANHA, J.M.R. \& MENEZES, M.S. 1998. Reproduction of the freshwater catfish Pimelodella pappenheimi in Southern Brazil. Stud. Neotrop. Fauna Environ. 33(2):106-110.

ARANHA, J.M., TAKEUTI, D.F. \& YOSHIMURA, T.M. 1998. Habitat use and food partitioning of fishes in a coastal stream of Atlantic Forest, Brazil. Rev. Biol. Trop. 46(4):951-960.

BOCKMANN, F.A. \& GUAZZELLI, G.M. 2003. Family Heptapteridae. In Check List of the Freshwater Fishes of South and Central America (R.E. Reis, S.O. Kullander \& C.J. FERRARIS, Ed.). EDIPUCRS, Porto Alegre, p.406-431.

BOWER, J.E. \& ZAR, J.H. 1984. Field and Laboratory Methods for General Ecology. Wm. C. Brown Publishers, Dubuque, Iowa.

CARMASSI, A.L., SILVA, A.T., RONDINELI, G.R. \& BRAGA, F.M.S. 2008 Population biology of Cyphocarax modestus (Osteichthyes, Curimatidae) in the Ribeirão Claro stream, Rio Claro (SP). Biota Neotrop. 8(1): http://www. biotaneotropica.org.br/v8n1/en/abstract?article+bn02308012008 (último acesso em 03/12/2009).

CASTRO, P.M.G., CERGOLE, M.C., CARNEIRO, M.H., MUCINHATO, C.M.D. \& SERVO, G.J.M. 2002. Crescimento, mortalidade e taxa de explotação do goete, Cynoscion jamaicensis (Perciformes: Sciaenidae), na região sudeste/sul do Brasil. Bol. Inst. Pesca 28(2):141-153.

CASTRO, R.M.C., CARAMASCHI, E.P., MAZZONI, R. \& PERES-NETO, P.R. 1999. Evolução da ictiofauna de riachos sul-americanos: padrões gerais e possíveis processos causais. Oecol. Bras. 6(1):139-155.

CATI/LUPA. 2008. http://www.cati.sp.gov.br/projetolupa/ (último acesso em 03/12/2009)

DE PINNA, M.C.C. 1998. Phylogenetic relationships of Neotropical Siluriformes (Teleostei: Ostariophysi): historical overview and synthesis of hypotheses. In Phylogeny and Classification of Neotropical Fishes (L.R. Malabarba, R.E. Reis, R.P. Vari, Z.M.S. Lucena \& C.A.S. Lucena eds). EDIPUCRS, Porto Alegre, p.279-330.

FERRARIS, C.J. 2007. Checklist of catfishes, recent and fossil (Osteichthyes: Siluriformes), and catalogue of siluriform primary types. Zootaxa 1418(1):1-628

GARUTTI, V. 1989. Contribuição ao conhecimento reprodutivo de Astyanax bimaculatus (Ostariophysi, Characidae), em cursos de água da bacia do Rio Paraná. Rev. Bras. Biol. 49(2):489-495

GAYANILO, F.C., SPARRE, P. \& PAULY, D. 2005. FAO-ICLARM stock assessment tools II (FiSAT II). Revised Version. User's guide. FAO, Rome.

GOMIERO, L.M., CARMASSI, A.L. \& BRAGA, F.M.S. 2007. Crescimento e mortalidade de Brycon opalinus (Characiformes, Characidae) no Parque Estadual da Serra do Mar, Mata Atlântica, Estado de São Paulo. Biota Neotrop. 7(1): http://www.biotaneotropica.org.br/v7n1/pt/ abstract?article+bn00207012007 (último acesso em 03/12/2009).

HAHN, N.S., FUGI, R., ALMEIDA, V.L.L., RUSSO, M.R., LOUREIRO, V.E., AGOSTINHO, A.A. \& GOMES, L.C. 1997. Dieta e atividade alimentar de peixes do reservatório de Segredo. In Reservatório de Segredo: bases ecológicas para o manejo (A.A. Agostinho \& L.C. Gomes, Ed.). EDUEM, Maringá, PR, p.141-162.
HUECK, K. \& SEIBERT, P. 1981. Vegetationskarte von Südamerika. Folia Geobot. 17(4):90.

HYSLOP, E.J. 1980. Stomach contents analysis-a review of methods and their application. J. Fish Biol. 17(4):411-429.

LANGEANI, F., CASTRO, R.M.C., OYAKAWA, O.T., SHIBATTA, O.A., PAVANELLI, C.S. \& CASATTI, L. 2007. Diversidade da ictiofauna do Alto Rio Paraná: composição atual e perspectivas futuras. Biota Neotrop. 7(3): http://www.biotaneotropica.org.br/v7n3/pt/ abstract?article+bn034070 32007 (último acesso em 03/12/2009).

LIZAMA, M. \& AMBROSIO, A. 2003. Crescimento, recrutamento e mortalidade do pequi Moenkhausia intermedia (Osteichthyes, Characidae) na planície de inundação do alto rio Paraná, Brasil. Acta Sci. Biol. Sci. 25(2):329-333.

LUNDBERG, J.G. \& LiTTMANN, M.W. 2003. Family Pimelodidae. In Check List of the Freshwater Fishes of South and Central America (R.E. Reis, S.O. Kullander \& C.J. FERRARIS, Ed.). EDIPUCRS, Porto Alegre, p.401-405.

LUNDBERG, J.G., MAGO-LECCIA, F. \& NASS, P. 1991. Exallodontus aguanai, a new genus and species of Pimelodidae (Pisces: Siluriformes) from deep river channels of South America, and delimitation of the subfamily Pimelodinae. Proc. Biol. Soc. Washington 104(4):840-869.

MACHADO-ALLISON, A. 1990. Ecologia de los peces de las areas inundables de los llanos de Venezuela. Interciência 15(6):411-423.

NIKOLSKY, G.V. 1963. The ecology of fish. Academic Press, London.

PAULY, D. 1980. On the interrelationships between natural mortality, growth parameters and mean environmental temperature in 175 fish stock. Int. Co. Explor. Sea 39(1):175-192.

PAULY, D. 1998. Tropical fishes: patterns and propensities. J. Fish Biol. 53(1):1-17.

ROSA, R.S. \& MENEZES, N.A. 1996. Relação preliminar das espécies de peixes (Pisces, Elasmobranchii, Actinopterygii) ameaçadas no Brasil Rev. Bras. Zool. 13(3):647-667.

SARMENTO-SOARES, L.M., MARTINS-PINHEIRO, R.F., ARANDA, A.T. \& CHAMON, C.C. 2006. Microglanis pataxo, a new catfish from Southern Bahia coastal rivers, northeastern Brazil (Siluriformes: Pseudopimelodidae). Neotrop. Ichthyol. 4(2):157-166.

SHIBATTA, O.A. \& BENINE, R.C. 2005. A new species of Microglanis (Siluriformes: Pseudopimelodidae) from upper rio Paraná basin, Brazil. Neotrop. Ichthyol. 3(4):579-585.

SHIBATTA, O.A. 2003. Family Pseudopimelodidae. In Check List of the Freshwater Fishes of South and Central America (R.E. Reis, S.O. Kullander \& C.J. FERRARIS, Ed.). EDIPUCRS, Porto Alegre, p.401-405.

TAYLOR, C.C. 1958. Cod growth and temperature. J. Cons. Int. Explor. Mer. 23(1):366-370.

TEIXEIRA, I. \& BENNEMANN, S.T. 2007. Ecomorphology reflect the fish diet in a reservoir in South Brazil. Biota Neotrop. 7(2): http://www. biotaneotropica.org.br/v7n2/pt/abstract?article+bn00807022 007 (último acesso em 03/12/2009).

VARI, R.P. 1992. Systematics of the Neotropical Characiform Genus Cyphocharax Fowler (Pisces: Ostariophysi). Smithson. Contrib. Zool. 529(1):1-137.

VAZZOLER, A.M. 1996. Biologia da Reprodução de Peixes Teleósteos: teoria e prática. Eduem, Maringá.

WINEMILLER, K.O. 1989. Patterns of variation in life history among South American fishes in seasonal environments. Oecologia 81(2):225-241.

Received 08/02/2010

Revised 16/08/2010

Accepted 20/08/2010 